\title{
Williamsia limnetica sp. nov., isolated from a limnetic lake sediment
}

\author{
Anil Sazak and Nevzat Sahin \\ Department of Biology, Faculty of Art and Science, Ondokuz Mayis University, \\ 55139 Kurupelit-Samsun, Turkey
}

Correspondence

Nevzat Sahin

nsahin@omu.edu.tr

\begin{abstract}
An actinomycete, strain $\mathrm{L} 1505^{\top}$, was isolated from a limnetic lake sediment and found to have morphological, biochemical, physiological and chemotaxonomic properties consistent with its classification in the genus Williamsia. Phylogenetic analysis based on 16S rRNA gene sequences revealed that strain $\mathrm{L}_{1505^{\top}}$ formed a distinct lineage within the genus Williamsia. The isolate belonged to a cluster containing $W$. muralis MA140/96 ${ }^{\top}, W$. marianensis $\mathrm{MT}^{\top}$ and $W$. faeni $\mathrm{N} 1350^{\top}$, with which the isolate shared 99.0-98.2\% 16S rRNA gene sequence similarity.

Genotypic and phenotypic data also indicated that the isolate was different from known members of the genus Williamsia. On the basis of these data, strain $1505^{\top}$ is considered to represent a novel species of the genus Williamsia, for which the name Williamsia limnetica sp. nov. is proposed (type strain $\mathrm{L} 1505^{\top}=\mathrm{DSM} 45521^{\top}=\mathrm{NRRL} \mathrm{B}-24829^{\top}=\mathrm{KCTC} 19981^{\top}$ ).
\end{abstract}

The genus Williamsia was proposed by Kämpfer et al. (1999) to accommodate an unusual actinomycete. At the time of writing, the genus Williamsia contained six recognized species, isolated from environmental samples [Williamsia maris (Stach et al., 2004), Williamsia marianensis (Pathomaree et al., 2006), Williamsia serinedens (Yassin et al., 2007) and Williamsia faeni (Jones et al., 2010)] and clinical materials [Williamsia muralis (Kämpfer et al., 1999) and Williamsia deligens (Yassin \& Hupfer, 2006)]. Members of the genus Williamsia form a clade within the evolutionary radiation occupied by mycolic-acid-containing actinomycetes of the suborder Corynebacterineae (Stackebrandt et al., 1997; Zhi et al., 2009) and are characterized by a number of chemical markers, including the presence of meso-diaminopimelic acid and the sugars arabinose, galactose, mannose and ribose (chemotype IV sensu Lechevalier \& Lechevalier, 1970). The predominant menaquinone types are MK-9 $\left(\mathrm{H}_{2}\right)$, MK-8 $\left(\mathrm{H}_{2}\right)$ (Kämpfer et al., 1999; Stach et al., 2004; Yassin \& Hupfer, 2006; Yassin et al., 2007) and MK$7\left(\mathrm{H}_{2}\right)$ and the mycolic acids have carbon chain lengths ranging from $\mathrm{C}_{50}$ to $\mathrm{C}_{58}$. The predominant fatty acids are octadecenoic acid, hexadecanoic acid, hexadecenoic acid and tuberculostearic acid. The polar lipid profile has major amounts of phosphatidylethanolamine, phosphatidylinositol, phosphatidylglycerol and diphosphatidylglycerol (phospholipid type II; Lechevalier et al., 1977).

An actinomycete, designated $\mathrm{L} 1505^{\mathrm{T}}$, was isolated from sediment of Iznik Lake, in the Marmara region in Turkey.

The GenBank/EMBL/DDBJ accession number for the 16S rRNA gene sequence of strain $L 1505^{\top}$ is $\mathrm{HQ1} 157192$.

Three supplementary figures are available with the online version of this paper.
Sediment samples were collected from the lake using a dredge at a depth of $3 \mathrm{~m}$. Samples were aseptically subsampled and stored at $-20{ }^{\circ} \mathrm{C}$ until use. Strain $\mathrm{L} 1505^{\mathrm{T}}$ was recovered from a suspension of the sample inoculated onto starch-casein agar (Küster, 1959) supplemented with $\left(\mathrm{ml}^{-1}\right)$ filter-sterilized cycloheximide $(50 \mu \mathrm{g})$, nystatin $(50 \mu \mathrm{g})$ and rifampicin $(0.5 \mu \mathrm{g})$. The organism was maintained on glucose-yeast extract malt-extract agar slopes $\left(\mathrm{l}^{-1}\right.$ distilled water: $4 \mathrm{~g}$ glucose, $4 \mathrm{~g}$ yeast extract, $10 \mathrm{~g}$ malt extract; $\mathrm{pH}$ 7.2) at room temperature and in $20 \%(\mathrm{v} / \mathrm{v})$ glycerol at $-20{ }^{\circ} \mathrm{C}$.

The colony, micro-morphological and staining characteristics of the isolate were determined using standard procedures, as described by Isik et al. (1999). The morphological and cultural characteristics were determined using ISP media 2-7 (Shirling \& Gottlieb, 1966), modified Bennett's agar (Jones, 1949), Czapek's agar (Weyland, 1969), glucose-yeast extractmalt extract agar (Shirling \& Gottlieb, 1966), nutrient agar (Difco) and trypticase soy agar (Difco). Colour name charts from the National Bureau of Standards (Kelly, 1964) were used to designate mycelial colours. The isolate and the most closely related members of the genus Williamsia (W. muralis DSM $44343^{\mathrm{T}}, W$. marianensis DSM $44944^{\mathrm{T}}$ and $W$. faeni DSM $45372^{\mathrm{T}}$ ) were examined for a range of phenotypic properties using well-established procedures (Gordon et al., 1974; Williams et al., 1983; Isik et al., 1999). Enzyme activities ( $\beta$-galactosidase, arginine dihydrolase, lysine decarboxylase, ornithine decarboxylase, citrate, $\mathrm{H}_{2} \mathrm{~S}$, urease, tryptophan deaminase, amygdalin and catalase) were examined qualitatively using the API $20 \mathrm{E}$ system (bioMérieux).

Strain $\mathrm{L} 1505^{\mathrm{T}}$ showed morphological properties consistent with its assignment to the genus Williamsia. The isolate formed smooth reddish-orange colonies on glucose-yeast extract malt-extract agar. Cells were rod- and coccoid-like 
(Fig. S1, available in IJSEM Online), Gram-stainingpositive and non-acid-alcohol-fast. The isolate grew well on most of the media tested, but not on ISP 3 or ISP 4 . Physiologically, strain $\mathrm{L} 1505^{\mathrm{T}}$ clearly differed from the reference strains. The isolate could be differentiated from $W$. muralis DSM $44343^{\mathrm{T}}$ by assimilation of $(+)$-D-cellobiose, dextrin, maltose, $(+)$-D-melezitose, $(+)$-D-melibiose and xylose, acid production from inositol and sorbitol, degradation of adenine and RNA, and catalase, $\beta$-galactosidase (ONPG) and tryptophan deaminase activities. The

Table 1. Phenotypic characteristics that differentiate strain $\mathrm{L} 1505^{\top}$ from its closest phylogenetic neighbours in the genus Williamsia

Strains: $1, \mathrm{~L} 1505^{\mathrm{T}} ; 2$, W. muralis DSM $44343^{\mathrm{T}} ; 3$, W. marianensis DSM $44944^{\mathrm{T}} ; 4$, W. faeni DSM $45372^{\mathrm{T}}$. +, Positive; \pm , weakly positive;

- , negative.

\begin{tabular}{|c|c|c|c|c|}
\hline Characteristic & 1 & 2 & 3 & 4 \\
\hline \multicolumn{5}{|l|}{ Degradation of: } \\
\hline Adenine & + & - & - & - \\
\hline Casein & - & - & + & - \\
\hline Gelatin & - & - & - & + \\
\hline Hypoxanthine & - & - & + & - \\
\hline RNA & + & - & + & + \\
\hline Starch & - & - & + & + \\
\hline Tween 20 & - & + & - & - \\
\hline Uric acid & + & - & + & + \\
\hline \multicolumn{5}{|c|}{ Sole carbon sources $(1 \%)$} \\
\hline Adonitol & - & + & - & + \\
\hline$(-)$-D-Arabinose & - & - & + & + \\
\hline$(-)$-D-Cellobiose & + & - & + & + \\
\hline (-)-D-Sorbitol & - & + & + & + \\
\hline$(+)$-D-Galactose & + & - & - & + \\
\hline$(+)$-D-Melezitose & + & - & - & - \\
\hline$(+)$-D-Melibiose & + & - & + & + \\
\hline Dextrin & + & - & - & - \\
\hline Inulin & - & - & - & + \\
\hline Lactose & - & - & - & + \\
\hline Maltose & + & - & - & + \\
\hline myo-Inositol & - & + & - & + \\
\hline Raffinose & - & - & - & + \\
\hline Xylitol & - & - & + & + \\
\hline Xylose & + & - & + & + \\
\hline \multicolumn{5}{|c|}{ Sole nitrogen sources $(0.1 \%)$} \\
\hline$\alpha$-Isoleucine & + & - & + & - \\
\hline D-Phenylalanine & - & - & - & + \\
\hline L-Methionine & - & - & - & + \\
\hline L-Phenylalanine & - & - & - & + \\
\hline L-Serine & + & - & + & + \\
\hline L-Threonine & - & \pm & + & - \\
\hline \multicolumn{5}{|l|}{ Biochemical tests } \\
\hline Aesculin & + & - & - & + \\
\hline Allantoin & - & - & \pm & + \\
\hline
\end{tabular}

physiological properties that differentiated strain $\mathrm{L} 1505^{\mathrm{T}}$ from the reference strains are shown in Table 1.

Biomass for chemotaxonomic study of strain $\mathrm{L} 1505^{\mathrm{T}}$ was prepared in glucose-yeast extract-malt extract broth with shaking at 160 r.p.m. for 10 days at $28{ }^{\circ} \mathrm{C}$. Cells were harvested by centrifugation, washed in distilled water, reharvested and freeze dried. Whole-cell hydrolysates were analysed for diaminopimelic acid isomers using TLC (Staneck \& Roberts, 1974) and for sugars using the method of Mikami \& Ishida (1983). Polar lipids were extracted and analysed by the method of Minnikin et al. (1984) as modified by Kroppenstedt \& Goodfellow (1991). The predominant isoprenoid quinones were extracted and purified by the method of Tindall (1990a, b) and determined by reversed-phase HPLC (Wu et al., 1989). Mycolic acid composition was determined at the DSMZ (Braunschweig, Germany) by using the standard Microbial Identification System (Microbial ID) for automated GC analysis, as described previously (Klatte et al., 1994). To quantify the whole-cell fatty acids, cells were first grown in $20 \mathrm{ml}$ trypticase soy broth (TSB) with shaking at 150 r.p.m. at $28{ }^{\circ} \mathrm{C}$, then, after 5 days, $5 \mathrm{ml}$ starter culture was inoculated into $50 \mathrm{ml}$ TSB, which was incubated as before for 5 days. After harvesting by cellulose membrane filtration $(0.45 \mu \mathrm{m}), 200 \mathrm{mg}$ wet cells were placed in an extraction tube. Cellular fatty acids were extracted, derivatized to their fatty acid methyl esters and analysed using the Microbial Identification System and a 6890N GC with a G2614A autosampler and a 6783 injector (Agilent Technologies) (Sasser, 1990; Kämpfer \& Kroppenstedt, 1996). Peaks were analysed using TSBA version 5.0. The DNA G $+C$ content was determined following the procedure developed by Gonzalez \& Saiz-Jimenez (2005).

The chemotaxonomic properties of the isolate were consistent with its assignment to the genus Williamsia (Kämpfer et al., 1999). Whole-cell hydrolysates contained meso-diaminopimelic acid as the only diamino acid of the peptidoglycan and arabinose and galactose as the major cell-wall sugars (wall chemotype IV sensu Lechevalier \& Lechevalier, 1970). The polar lipid profile was composed of phosphatidylethanolamine, phosphatidylinositol, diphosphatidylglycerol and three unknown polar lipids (phospholipid type II sensu Lechevalier et al., 1977) (Fig. S2). The quinone system consisted of MK-8 $\left(\mathrm{H}_{2}\right) \quad(48.7 \%)$, MK-9 $\left(\mathrm{H}_{2}\right) \quad(34.6 \%)$ and MK-7 $\left(\mathrm{H}_{2}\right)$ $(16.5 \%)$ (Fig. S3). The major fatty acids were $\mathrm{C}_{18: 1} 9 \mathrm{c}$ (30.68\%), $\mathrm{C}_{16: 0}(28.86 \%), \mathrm{C}_{16: 1} 9 t(16.98 \%)$ and 10-methyl $\mathrm{C}_{18: 0}(14.03 \%)$. Small amounts of $\mathrm{C}_{18: 0}(4.68 \%), \mathrm{C}_{14: 0}$ $(2.67 \%)$ and $\mathrm{C}_{16: 1}(1.01 \%)$ were also found. The mycolic acid major-chain lengths ranged from $\mathrm{C}_{52}$ to $\mathrm{C}_{58}\left(12 \% \mathrm{C}_{52}, 2 \%\right.$ $\mathrm{C}_{53}, 31 \% \mathrm{C}_{54}, 4 \% \mathrm{C}_{55}, 38 \% \mathrm{C}_{56}, 2 \% \mathrm{C}_{57}$ and $\left.11 \% \mathrm{C}_{58}\right)$. The $\mathrm{G}+\mathrm{C}$ content of the DNA was $65.1 \mathrm{~mol} \%$.

Preparation of genomic DNA and amplification of the $16 \mathrm{~S}$ rRNA gene were carried out following Chun \& Goodfellow (1995) and sequencing was performed using an automatic sequencer (3730XL; ABI PRISM). The identification of phylogenetic neighbours and the calculation of pairwise 


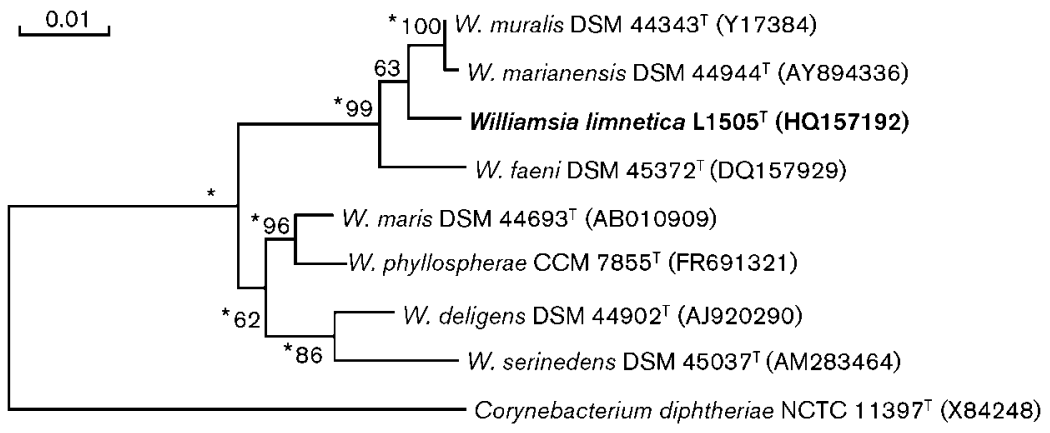

Fig. 1. Neighbour-joining tree based on nearly complete 16S RNA gene sequences showing the position of strain $\mathrm{L}_{1505^{\top}}$ in the genus Williamsia. Bootstrap values ( $>50 \%$ ) based on 1000 resamplings are shown at branch nodes. Asterisks indicate that the corresponding nodes were recovered in trees generated with the maximum-likelihood and maximum-parsimony algorithms. Bar, 0.01 substitutions per site.
16S rRNA gene sequence similarities were achieved using BLAST (http://www.ncbi.nlm.nih.gov/blast/). CLUSTAL w version 1.8 (Thompson et al., 1994) was used to align the sequence of strain $\mathrm{L} 1505^{\mathrm{T}}$ with those of related taxa retrieved from public databases. Phylogenetic trees were inferred using neighbour-joining (Saitou \& Nei, 1987) and maximum parsimony (Fitch, 1971) in MEGA version 3 (Kumar et al., 2004) and maximum likelihood (Felsenstein, 1981) in the PHYLIP suite of programs (Felsenstein, 1993). The evolutionary distance model of Jukes \& Cantor (1969) was used to generate evolutionary distance matrices for the neighbour-joining algorithm. The topologies of the resultant trees were evaluated using bootstrap analysis (Felsenstein, 1985) based on 1000 resamplings of the neighbour-joining dataset with the CONSENSE and SEQBOOT options in the PHYLIP package.

An almost-complete (1460 nt) 16S rRNA gene sequence for strain $\mathrm{L} 1505^{\mathrm{T}}$ was obtained and compared with corresponding sequences from representatives of genera in the suborder Corynebacterineae. Strain $\mathrm{L} 1505^{\mathrm{T}}$ contained signature nucleotides that are characteristic for members of the family Nocardiaceae (Stackebrandt et al., 1997), except at positions 139-224 (A: U), 843 (U) and 1189 (U) (Escherichia coli numbering system). Furthermore, strain $\mathrm{L} 1505^{\mathrm{T}}$ contained signature nucleotides that are shared with other members of the genus Williamsia [at positions 293-304 (G:C), 307 (C) and 1007-1022 (C:G)] (Yassin \& Hupfer, 2006; Yassin et al., 2007). The phylogenetic tree based on the neighbour-joining algorithm showed that strain $\mathrm{L} 1505^{\mathrm{T}}$ formed a cluster with $W$. muralis MA140/96 ${ }^{\mathrm{T}}, W$. marianensis $\mathrm{MT}^{\mathrm{T}}$ and $W$. faeni $\mathrm{N} 1350^{\mathrm{T}}$ (Fig. 1). Strain $\mathrm{L}_{1505^{\mathrm{T}}}$ exhibited 16S rRNA gene sequence similarity of $99.0 \%$ (14 nt differences over $1455 \mathrm{nt}$ ), $98.8 \%$ (16 nt differences over $1433 \mathrm{nt}$ ) and $98.29 \%$ (24 nt differences over $1406 \mathrm{nt}$ ) with $W$. muralis MA140/96 ${ }^{\mathrm{T}}, W$. marianensis $\mathrm{MT}^{\mathrm{T}}$ and $W$. faeni $\mathrm{N} 1350^{\mathrm{T}}$, respectively.

DNA-DNA relatedness between strain $21505^{\mathrm{T}}$ and the reference strains was determined by the identification service at the DSMZ. DNA was isolated using a French pressure cell (Thermo Spectronic) and purified by chromatography on hydroxyapatite as described by Cashion et al. (1977). DNADNA hybridization was carried out as described by De Ley et al. (1970) incorporating the modifications described by Huss et al. (1983) using a model Cary 100 Bio UV/VISspectrophotometer equipped with a Peltier-thermostatted
$6 \times 6$ multicell changer and a temperature controller with in situ temperature probe (Varian). DNA-DNA relatedness was calculated as the mean of duplicate determinations. The taxonomic integrity of the isolate was supported by the hybridization study. Strain $\mathrm{L} 1505^{\mathrm{T}}$ exhibited $18.8 \%$ DNA-DNA relatedness to $W$. muralis DSM $44343^{\mathrm{T}}$ and $W$. marianensis DSM $44944^{\mathrm{T}}$ and $22.4 \%$ DNA-DNA relatedness to $W$. faeni DSM $45372^{\mathrm{T}}$. These values are clearly well below the $70 \%$ threshold proposed by Wayne et al. (1987) for the delineation of separate species.

It is apparent from the genotypic, chemotaxonomic and phenotypic data that strain $\mathrm{L} 1505^{\mathrm{T}}$ represents a novel species of the genus Williamsia. The name Williamsia limnetica sp. nov. is proposed.

\section{Description of Williamsia limnetica sp. nov.}

Williamsia limnetica (lim.ne'ti.ca. N.L. fem. adj. limnetica limnetic, isolated from lake sediment, the source of the organism).

Forms smooth, reddish-orange colonies on glucose-yeast extract malt-extract agar at $28{ }^{\circ} \mathrm{C}$ after 7 days. Cells are Gram-positive-staining rod- and coccoid-like elements (0.6-1.0 $\mu \mathrm{m}$ wide, $1.4-1.8 \mu \mathrm{m}$ long) and are non-acidalcohol-fast. Grows well on ISP 2, ISP 5, ISP 6, ISP 7, modified Bennett's agar, Czapek's agar, glucose-yeast extract-malt extract agar, nutrient agar and trypticase soy agar. Grows at $10-37{ }^{\circ} \mathrm{C}$ (optimum $28{ }^{\circ} \mathrm{C}$ ), but not at 4 or $45{ }^{\circ} \mathrm{C}$, and grows with $0-4 \%(\mathrm{w} / \mathrm{v}) \mathrm{NaCl}$. Positive for $\beta$ galactosidase (ONPG), catalase and urease, but negative for arginine dihydrolase, lysine decarboxylase, ornithine decarboxylase and citrate and $\mathrm{H}_{2} \mathrm{~S}$ production. Tests for nitrate reduction and aesculin and urea hydrolysis are positive, but those for allantoin and arbutin hydrolysis are negative. Degrades adenine, DNA, RNA and uric acid, but does not degrade casein, chitin, elastin, gelatin, guanine, hypoxanthine, starch, Tweens 20 and 80 , xanthine or xylan. As sole sources of carbon for energy and growth, assimilates $(-)$-D-cellobiose, dextrin, $(-)$-D-fructose, $(+)$ D-galactose, maltose, D-mannitol, $(+)$-D-mannose, $(+)$-Dmelezitose, (+)-D-melibiose, (+)-L-rhamnose, (-)-Dglucose, sucrose and xylose, but does not assimilate adonitol, (-)-D-arabinose, inulin, lactose, (-)-D-salicin, $(-)$-D-sorbitol, (-)-L-sorbose, L-glutamate, myo-inositol, raffinose or xylitol. As sole sources of nitrogen, utilizes 
isoleucine, glycine, L-alanine, L-arginine, leucine, L-histidine, L-proline, L-serine and L-valine, but does not utilize D-phenylalanine, L-cysteine, L-hydroxyproline, L-methionine, L-phenylalanine or L-threonine. The quinone system consists of $\mathrm{MK}-8\left(\mathrm{H}_{2}\right)$, MK- $9\left(\mathrm{H}_{2}\right)$ and $\mathrm{MK}-7\left(\mathrm{H}_{2}\right)$. The major fatty acids are octadecenoic acid $\left(\mathrm{C}_{18: 1} 9 c\right)$, hexadecanoic acid $\left(\mathrm{C}_{16: 0}\right)$ and tuberculostearic acid (10-methyl $\left.\mathrm{C}_{18: 0}\right)$. Mycolic acids with 52-58 carbons are present.

The type strain, $\mathrm{L}^{\mathrm{T}} 155^{\mathrm{T}} \quad\left(=\mathrm{DSM} \quad 45521^{\mathrm{T}}=\mathrm{NRRL}\right.$ B-24829 ${ }^{\mathrm{T}}=$ KCTC $19981^{\mathrm{T}}$ ), was isolated from limnetic lake sediment of Iznik Lake, Bursa, Turkey. The genomic DNA $\mathrm{G}+\mathrm{C}$ content of the type strain is $65.1 \mathrm{~mol} \%$.

\section{Acknowledgements}

This research was supported by Ondokuz Mayis University (OMU) (project no. PYO. FEN. 1901.09.003). The authors are indebted to Professor Dr Kiymet Guven (University of Anadolu) for help with the fatty acid analysis.

\section{References}

Cashion, P., Holder-Franklin, M. A., McCully, J. \& Franklin, M. (1977). A rapid method for the base ratio determination of bacterial DNA. Anal Biochem 81, 461-466.

Chun, J. \& Goodfellow, M. (1995). A phylogenetic analysis of the genus Nocardia with 16S rRNA gene sequences. Int J Syst Bacteriol 45, 240-245.

De Ley, J., Cattoir, H. \& Reynaerts, A. (1970). The quantitative measurement of DNA hybridization from renaturation rates. Eur $J$ Biochem 12, 133-142.

Felsenstein, J. (1981). Evolutionary trees from DNA sequences: a maximum likelihood approach. J Mol Evol 17, 368-376.

Felsenstein, J. (1985). Confidence limits on phylogeny: an approach using the bootstrap. Evolution 39, 783-791.

Felsenstein, J. (1993). PHYLIP (phylogenetic inference package), version 3.5c. Seattle: Department of Genetics, University of Washington, USA.

Fitch, W. M. (1971). Toward defining the course of evolution: minimum change for a specific tree topology. Syst Zool 20, 406-416.

Gonzalez, J. M. \& Saiz-Jimenez, C. (2005). A simple fluorimetric method for the estimation of DNA-DNA relatedness between closely related microorganisms by thermal denaturation temperatures. Extremophiles 9, 75-79.

Gordon, R. E., Barnett, D. A., Handerhan, J. E. \& Pang, C. H.-N. (1974). Nocardia coeliaca, Nocardia autotrophica, and the nocardin strain. Int J Syst Bacteriol 24, 54-63.

Huss, V. A. R., Festl, H. \& Schleifer, K. H. (1983). Studies on the spectrophotometric determination of DNA hybridization from renaturation rates. Syst Appl Microbiol 4, 184-192.

Isik, K., Chun, J., Hah, Y. C. \& Goodfellow, M. (1999). Nocardia salmonicida nom. rev., a fish pathogen. Int J Syst Bacteriol 49, 833837.

Jones, K. L. (1949). Fresh isolates of actinomycetes in which the presence of sporogenous aerial mycelia is a fluctuating characteristic. J Bacteriol 57, 141-145.

Jones, A. L., Payne, G. D. \& Goodfellow, M. (2010). Williamsia faeni sp. nov., an actinomycete isolated from a hay meadow. Int J Syst Evol Microbiol 60, 2548-2551.
Jukes, T. H. \& Cantor, C. R. (1969). Evolution of protein molecules. In Mammalian Protein Metabolism, vol. 3, pp. 21-132. Edited by H. N. Munro. New York: Academic Press.

Kämpfer, P. \& Kroppenstedt, R. M. (1996). Numerical analysis of fatty acid patterns of coryneform bacteria and related taxa. Can $J$ Microbiol 42, 989-1005.

Kämpfer, P., Andersson, M. A., Rainey, F. A., Kroppenstedt, R. M. \& Salkinoja-Salonen, M. (1999). Williamsia muralis gen. nov., sp. nov., isolated from the indoor environment of a children's day care centre. Int J Syst Bacteriol 49, 681-687.

Kelly, K. L. (1964). Inter-Society Color Council - National Bureau of Standards Color Name Charts Illustrated with Centroid Colors. Washington, DC: US Government Printing Office.

Klatte, S., Rainey, F. A. \& Kroppenstedt, R. M. (1994). Transfer of Rhodococcus aichiensis Tsukamura 1982 and Nocardia amarae Lechevalier and Lechevalier 1974 to the genus Gordona as Gordona aichiensis comb. nov. and Gordona amarae comb. nov. Int J Syst Bacteriol 44, 769-773.

Kroppenstedt, R. M. \& Goodfellow, M. (1991). The family Thermomonosporaceae. In The Prokaryotes, 2nd edn, pp. 1085-1114. Edited by A. Balows, H. G. Trüper, M. Dworkin, W. Harder \& K. H. Schleifer. New York: Springer.

Kumar, S., Tamura, K. \& Nei, M. (2004). MEGA3: integrated software for Molecular evolutionary genetics analysis and sequence alignment. Brief Bioinform 5, 150-163.

Küster, E. (1959). Outline of a comparative study of criteria used in characterization of the actinomycetes. Int Bull Bacteriol Nomencl Taxon 9, 97-104.

Lechevalier, M. P. \& Lechevalier, H. A. (1970). Chemical composition as a criterion in the classification of aerobic actinomycetes. Int J Syst Bacteriol 20, 435-443.

Lechevalier, M. P., De Bievre, C. \& Lechevalier, H. A. (1977). Chemotaxonomy of aerobic actinomycetes: phospholipid composition. Biochem Syst Ecol 5, 249-260.

Mikami, H. \& Ishida, Y. (1983). Post-column fluorometric detection of reducing sugars in high-performance liquid chromatography using arginine. Bunseki Kagaku 32, E207-E210.

Minnikin, D. E., O'Donnell, A. G., Goodfellow, M., Alderson, G., Athalye, M., Schaal, A. \& Parlett, J. H. (1984). An integrated procedure for the extraction of bacterial isoprenoid quinones and polar lipids. J Microbiol Methods 2, 233-241.

Pathom-aree, W., Nogi, Y., Sutcliffe, I. C., Ward, A. C., Horikoshi, K., Bull, A. T. \& Goodfellow, M. (2006). Williamsia marianensis sp. nov., a novel actinomycete isolated from the Mariana Trench. Int J Syst Evol Microbiol 56, 1123-1126.

Saitou, N. \& Nei, M. (1987). The neighbor-joining method: a new method for reconstructing phylogenetic trees. Mol Biol Evol 4, 406425 .

Sasser, M. (1990). Identification of bacteria by gas chromatography of cellular fatty acids. Technical Note 101. Newark, DE: MIDI Inc.

Shirling, E. B. \& Gottlieb, D. (1966). Methods for characterization of Streptomyces species. Int J Syst Bacteriol 16, 313-340.

Stach, J. E., Maldonado, L. A., Ward, A. C., Bull, A. T. \& Goodfellow, M. (2004). Williamsia maris sp. nov., a novel actinomycete isolated from the Sea of Japan. Int J Syst Evol Microbiol 54, 191-194.

Stackebrandt, E., Rainey, F. A. \& Ward-Rainey, N. L. (1997). Proposal for a new hierarchic classification system, Actinobacteria classis nov. Int J Syst Bacteriol 47, 479-491.

Staneck, J. L. \& Roberts, G. D. (1974). Simplified approach to identification of aerobic actinomycetes by thin-layer chromatography. Appl Microbiol 28, 226-231. 
Thompson, J. D., Higgins, D. G. \& Gibson, T. J. (1994). CluSTAL W: improving the sensitivity of progressive multiple sequence alignment through sequence weighting, position-specific gap penalties and weight matrix choice. Nucleic Acids Res 22, 4673-4680.

Tindall, B. J. (1990a). A comparative study of the lipid composition of Halobacterium saccharovorum from various sources. Syst Appl Microbiol 13, 128-130.

Tindall, B. J. (1990b). Lipid composition of Halobacterium lacusprofundi. FEMS Microbiol Lett 66, 199-202.

Wayne, L. G., Brenner, D. J., Colwell, R. R., Grimont, P. A. D., Kandler, O., Krichevsky, M. I., Moore, L. H., Moore, W. E. C., Murray, R. G. E. \& other authors (1987). Report of the ad hoc committee on reconciliation of approaches to bacterial systematics. Int J Syst Bacteriol 37, 463-464.

Weyland, H. (1969). Actinomycetes in North Sea and Atlantic Ocean sediments. Nature 223, 858.
Williams, S. T., Goodfellow, M., Alderson, G., Wellington, E. M. H., Sneath, P. H. A. \& Sackin, M. J. (1983). Numerical classification of Streptomyces and related genera. J Gen Microbiol 129, 1743-1813.

Wu, C., Lu, X., Qin, M., Wang, Y. \& Ruan, J. (1989). Analysis of menaquinone compound in microbial cells by HPLC. Microbiology [English translation of Microbiology (Beijing)] 16, 176-178.

Yassin, A. F. \& Hupfer, H. (2006). Williamsia deligens sp. nov., isolated from human blood. Int J Syst Evol Microbiol 56, 193-197.

Yassin, A. F., Young, C. C., Lai, W.-A., Hupfer, H., Arun, A. B., Shen, F.-T., Rekha, P. D. \& Ho, M.-J. (2007). Williamsia serinedens sp. nov., isolated from an oil-contaminated soil. Int J Syst Evol Microbiol 57, 558-561.

Zhi, X.-Y., Li, W.-J. \& Stackebrandt, E. (2009). An update of the structure and 16S rRNA gene sequence-based definition of higher ranks of the class Actinobacteria, with the proposal of two new suborders and four new families and emended descriptions of the existing higher taxa. Int J Syst Evol Microbiol 59, 589-608. 